\title{
Biologic and climatic signals in the oxygen isotopic composition of Eocene-Oligocene equid enamel phosphate
}

\author{
J. Daniel Bryant ${ }^{a, *}$, Philip N. Froelich ${ }^{b}$, William J. Showers ${ }^{c}$, Bernard J. Genna ${ }^{c}$ \\ a Department of Geosciences, Princeton University, Princeton, NJ 08544-1003, USA \\ ${ }^{b}$ School of Earth and Atmospheric Sciences, Georgia Institute of Technology, Atlanta, GA 30332-0340, USA \\ ${ }^{\mathrm{c}}$ Department of Marine, Earth, and Atmospheric Sciences, North Carolina State University, Raleigh, NC 27695-8208, \\ USA
}

Received 26 June 1995; revision 29 August 1995; accepted 2 May 1996

\begin{abstract}
Oxygen isotope results for tooth enamel-phosphate $\left(\delta_{\mathbf{p}}\right)$ from late Eocene-early Oligocene fossil horses are presented to determine if paleobiologic and paleoclimatologic information is recorded in fossil tooth enamel chemistry. Teeth from jaws of Mesohippus and Miohippus from the White River Formation (or Group) in the western Great Plains are well preserved and have excellent geochronologic control. Although there is clear evidence for post-depositional alteration of the enamel, a hydroxylapatite mineralogy is preserved and isotopic exchange of oxygen does not appear to be significant. There are distinctive patterns of $\delta_{\mathrm{P}}$ variation among individual teeth from the same jaw. These patterns reflect season of birth and timing of enamel mineralization. Most of the horses were born in the spring, and mineralization of the enamel is complete after 1-1.5 years. These results show that paleoclimate reconstruction from enamel $\delta_{\mathrm{p}}$ must account for tooth position and timing of mineralization. The observation that there are different intrajaw patterns of $\delta_{\mathrm{P}}$ variation among Mesohippus and Miohippus may provide a basis to reconstruct changes in climate seasonality in ancient environments.
\end{abstract}

Keywords: stable isotopes; apatite; Equidae

\section{Introduction}

The $\delta^{18} \mathrm{O}$ of tooth enamel-phosphate from fossil mammals $\left(\delta_{\mathrm{P}}\right)$ has promise as a quantitative continental paleoclimate proxy (Longinelli, 1974). Although there have been several attempts at climate reconstruction using $\delta^{18} \mathrm{O}$ of mammalian biogenic phosphate (D'Angela, 1991; Ayliffe et al., 1992; D'Angela and Longinelli, 1993; Bryant et al.,

* Corresponding author. Telephone: (609) 258-2612; Fax: (609)

258-1274; E-mail: jdbryant@geo.princeton.edu
1994; Sánchez Chillón et al., 1994), most of these studies have found considerable unexplained variation. Tooth enamel is the preferred biogenic phosphate phase for paleoclimate reconstruction because it is considered the most resistant to diagenesis (Lee Thorp and Van der Merwe, 1991; Ayliffe et al., 1992, 1994; Bryant, 1995). Characteristic patterns of variation in $\delta_{\mathrm{p}}$ among different teeth within the same jaw of modern and Miocene horses are interpreted to result from season of birth and timing of enamel mineralization (Bryant et al., 1996). These effects lead to 
very large differences in $\delta_{\mathbf{P}}$ among the individual teeth in a jaw. Similar patterns in $\delta_{p}$ occur in tooth enamel from bison and sheep (Fricke and O'Neil, 1996). The patterns and processes leading to intrajaw $\delta_{\mathrm{P}}$ variation must be understood before continental paleoclimate reconstruction is viable. These patterns also provide new insight into the paleobiology of ancient horses. The purposes of this paper are to (1) demonstrate characteristic patterns of $\delta_{\mathrm{P}}$ variation found in teeth of late Eocene-early Oligocene fossil horse jaws from the White River Group in the western Great Plains of the U.S., and (2) discuss the significance of these patterns for paleobiological and paleoclimatological applications.

Patterns of $\delta_{\mathrm{P}}$ variation in teeth from jaws of Miocene and modern horse (equid) teeth provide evidence of the season of birth and overall seasonality of the birth cycle in ancient horse faunas (Bryant et al., 1996). Based on these results, Miocene horses were, in broad terms, relatively similar to modern horses in terms of the timing of enamel mineralization, seasonal birth cycles, and season of birth. From a paleobiological viewpoint, however, horses from the late Eocene and early Oligocene (Mesohippus and Miohippus) were very different from Miocene and modern horses. Mesohippus and Miohippus were much smaller, their teeth were brachydont, and they lived in much more wooded biomes and had very different diets than Miocene and typical modern wild populations of equids (MacFadden, 1986; Retallack, 1983,1992; Janis, 1990). Thus it is reasonable to expect that the intrajaw $\delta_{\mathrm{P}}$ patterns may also be very different.

Quantitative climate reconstruction may be possible once the intrajaw $\delta_{\mathrm{P}}$ patterns are understood. The late Eocene-early Oligocene is an important period in Earth's climate history. Following the Eocene thermal maximum, a long period of cooling in the middle and late Eocene culminated with the "Terminal Eocene Event" (TEE; Wolfe, 1978), now known to be early Oligocene. The TEE is the most abrupt climate shift in the Paleogene and represents the final transition from the warmer climates of the Eocene to the cooler climates of the Oligocene, reflected globally in marine and continental climate archives (e.g., Wolfe,
1978, 1992; Miller, 1992; Zachos et al., 1993). The TEE was first defined by Wolfe (1978) on the basis of fossil leaf assemblages from the western U.S., and is interpreted to be a $7-8^{\circ} \mathrm{C}$ cooling in mean annual temperature (Wolfe, 1992, 1994). Climate deterioration in the late Eocene-early Oligocene associated with the TEE is reflected in the White River Group in paleosol morphology (Retallack, 1983, 1992), other detailed aspects of sedimentology (Clark et al., 1967), and fossil land snail, amphibian, and reptile faunas (Evanoff et al., 1992; Hutchison, 1992), all of which record progressively more arid environments during the late Eocene and early Oligocene. There are several minor pulses of mammal turnover (Janis, 1989, 1993; Prothero, 1989, 1994).

The timing of the TEE in marine records is well known. The TEE occurs within Chron $\mathrm{C} 13 \mathrm{n}$ in the marine record (Miller, 1992), between 33.1 and $33.5 \mathrm{Ma}$. The timing of the TEE in terrestrial records is not as well constrained, but occurred at about $33 \mathrm{Ma}$ (Wolfe, 1994) and is presumably contemporaneous with the marine record. The TEE followed just after the Eocene-Oligocene boundary at $33.7 \mathrm{Ma}$ (Cande and Kent, 1992). The White River Group is one of the best exposed and most fossiliferous continental EoceneOligocene sections. A detailed litho- and paleomagnetic stratigraphy and ${ }^{40} \mathrm{Ar} /{ }^{39} \mathrm{Ar}$ dates for several ashes (Swisher and Prothero, 1990; Prothero and Swisher, 1992) provide outstanding geochronologic control. Fossil mammals are abundant, well-preserved, and often collected with detailed stratigraphic information. Fossil equids are common elements in White River faunas (Prothero and Shubin, 1989).

Analyses of fossil enamel $\delta_{\mathrm{p}}$ from the White River Group might provide records of continental paleoclimate change during this important time interval. Fossils from the White River Group meet the following important prerequisites for climate reconstruction: (1) the fossils are well-preserved, (2) fossils are common, (3) there is outstanding geochronologic control, (4) other climate-sensitive records are available, such as paleosols and fossil faunas, and (5) there are large climate shifts preserved in many archives worldwide at this time, including in the White River Group. Fossil mam- 
mals are more common and more widely distributed in space and time than fossil leaf floras that are sufficiently diverse and well preserved for leaf physiognomy studies (Wolfe, 1993).

Fossil horses are particularly well suited for analysis for the following reasons: (1) horses are very common in the fossil record and widely distributed in time and space (MacFadden, 1992). They have a $\sim 58$ million year history and are found for at least part of that history on every continent except Australia and Antarctica. Horses are often the most common element in late Paleogene and Neogene fossil mammal faunas. (2) Equid phylogeny is relatively well known, providing a phylogenetic framework. (3) There are a number of studies of paleodiet, body size, and other evolutionary and paleobiological aspects for fossil equids. Horses show evolutionary responses to paleoecologic and paleoclimatologic change. Indeed, horses are the classic example used for nearly every evolutionary theory. (4) Horses are generally large in size relative to other fossil taxa and they can be identified easily, which greatly simplifies sample selection and preparation. Furthermore, large mammals have many advantages for climate reconstruction over smaller taxa due to physiological effects on $\delta^{18} \mathrm{O}$ fractionation in body water (Bryant and Froelich, 1995). (5) Horses often provide strong biostratigraphic control, and thus good evidence of geologic age. (6) Living zebras and horses are widely available and provide modern analogs. Thus the fossil horses from White River Group provide an excellent opportunity for quantitative paleoclimate reconstruction.

Continental climate reconstruction from $\delta_{\mathrm{p}}$ of mammalian biogenic phosphate relies on a threestep hypothesis (Fig. 1). The $\delta^{18} \mathrm{O}$ of the animal's oxygen inputs (water, metabolic oxygen derived from oxidation of organic compounds in food, and atmospheric $\mathrm{O}_{2}$ ) are all directly or indirectly related to climate via fractionation in the hydrologic cycle and surficial processes. In turn the $\delta^{18} \mathrm{O}$ of body water reflects the balance of these oxygen inputs, which is controlled by body mass-dependent fluxes of oxygen through the body (Bryant and Froelich, 1996). Mammalian $\delta_{\mathrm{P}}$ precipitates in equilibrium with body water ( $\mathrm{Luz}$

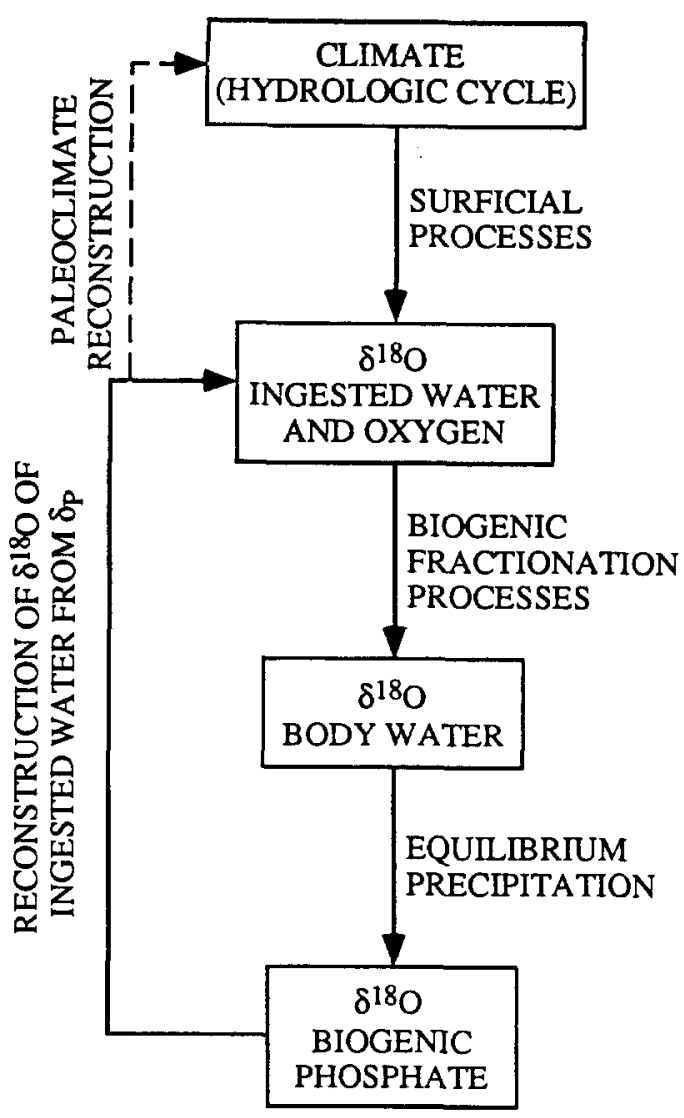

Fig. 1. Schematic outline of climate reconstruction from the $\delta^{18} \mathrm{O}$ of mammalian biogenic phosphate. Climatic processes and the hydrologic cycle control the $\delta^{18} \mathrm{O}$ of local precipitation, which in turn is fractionated by surficial processes and controls the $\delta^{18} \mathrm{O}$ of ingested water and metabolic oxygen. The $\delta^{18} \mathrm{O}$ of body water is determined by vital (biological) fractionation relative to oxygen inputs (water, metabolic oxygen, and atmospheric $\mathrm{O}_{2}$ ). Mammalian biogenic phosphate precipitates in isotopic equilibrium with body water at $37^{\circ} \mathrm{C}$. If the vital effects are known, the $\delta^{18} \mathrm{O}$ of mammalian biogenic phosphate can be used to estimate the $\delta^{18} \mathrm{O}$ of ingested water, which reflects climate.

et al., 1984). Because mammalian body temperature is constant near $37^{\circ} \mathrm{C}, \delta_{\mathrm{P}}$ is not influenced by environmental temperature and reflects only the $\delta^{18} \mathrm{O}$ of oxygen inputs and mass balance in the body. Hence with basic knowledge of body size and ecophysiological habits of an extinct species (e.g., large herbivore), a quantitative, isotopic record of continental climate might be reconstructed from $\delta_{\mathrm{P}}$. 


\section{Tooth mineralization and eruption in equids}

The sequence and timing of cheek tooth mineralization and eruption in modern equids are well known and similar in domestic horses and zebras (Erz, 1964; Levine, 1982; Penzhorn, 1982). The deciduous premolars are erupted at birth (Fig. 2). The first permanent tooth to erupt through the bone (although not necessarily to enter wear) is the $\mathrm{M} 1$ at $7-12$ months. The M2 erupts at about 16-24 months, and P2 and P3 erupt at 2.5-3.5 years. The last teeth to erupt are P4 and finally M3 between 3-5 years. The lower cheek teeth erupt slightly later (1-2 months) than the equivalent uppers.

A

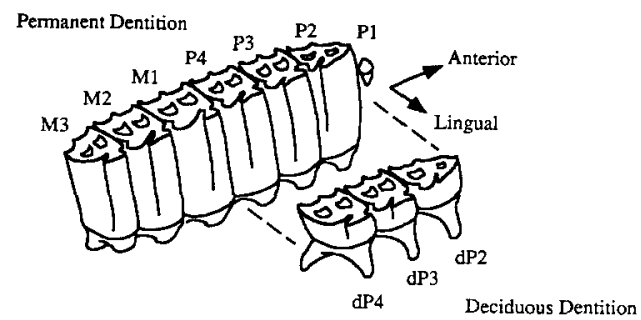

B

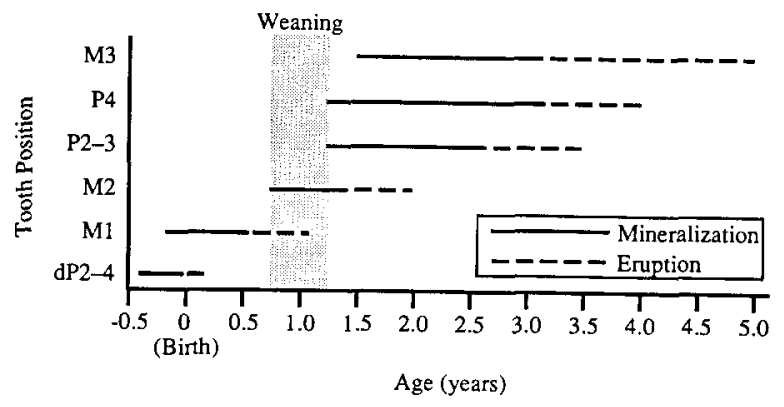

Fig. 2. A,B. Dental nomenclature and tooth enamel mineralization timing and sequence in zebras and domestic horses. A. Dental nomenclature, based on upper cheek teeth (after Hillson, 1986). Upper teeth are designated with upper case letters, $P$ for premolar and $M$ for molar, followed by a number for relative position in the jaw ( 1 is the most anterior). B. Mineralization and eruption timing and sequence (Erz, 1964; Levine, 1982; Penzhorn, 1982; Hillson, 1986). The range in timing indicated for mineralization and eruption reflect observed ranges in modern taxa, not the amount of time required for the mineralization and eruption sequence once the process is initiated for a tooth. Lower cheek teeth mineralize and erupt weeks to months after the equivalent upper cheek teeth. Mineralization of P2-P4 and $\mathrm{M} 3$ occurs after weaning, so $\delta^{18} \mathrm{O}$ of enamel is free of the effects of nursing on the $\delta^{18} \mathrm{O}$ of body water.
The timing of enamel mineralization is critical for tooth chemistry. Mineralization begins several months to over a year before eruption. Weaning of zebra, feral horses, and domestic horses occurs at 9-15 months of age. Foals rarely drink water before weaning (Crowell-Davis et al., 1985; Berger, 1986; Becker and Ginsberg, 1990). The deciduous premolars mineralize before birth, and the $\mathrm{M} 1$ and M2 mineralize wholly or partially before weaning. The chemistry of these teeth reflects the influence of the mare's body water through prenatal development and nursing. The remaining permanent teeth form sufficiently late that their chemical signature is free from effects of nursing.

The sequence of tooth eruption in Eocene Oligocene fossil horses is the same as for modern horses and zebras. The age at which teeth erupted in the fossil taxa, however, is unknown. In Miocene horses it appears that the age at which eruption of individual teeth occurred was probably about the same or slightly earlier than in modern horses and zebras (Van Valen, 1964; Hulbert, 1984). Eocene--Oligocene horses were considerably smaller $(40-50 \mathrm{~kg})$ than Miocene or modern species (MacFadden, 1986). Longevity in mammals is related to body size (Blueweiss et al., 1978), hence the Eocene-Oligocene horses also likely had relatively shorter lifespans than Miocene and modern equids. Furthermore, the EoceneOligocene horses had more brachydont teeth. The timing of tooth mineralization was, therefore, probably accelerated relative to modern and Miocene horses. Differences in the timing of tooth mineralization and season of birth are expected to affect the patterns in $\delta_{\mathrm{P}}$ observed among teeth from the same jaw, as will be shown below.

\section{Materials and methods}

\subsection{Samples and stratigraphy}

Samples are isolated teeth and individual teeth from jaws, all upper teeth except one lower $\mathrm{m} 1$. All of the teeth preserved in each jaw were analyzed, and the number of teeth measured from a jaw ranges from one to six. Jaws of Miohippus and Mesohippus from the White River Group in South 
Dakota and Wyoming (Table 1 and Fig. 3) were selected from the Frick Collection of fossil mammals at the American Museum of Natural History. Each jaw has detailed stratigraphic information, often within the nearest $\sim 0.3 \mathrm{~m}$ of widely mapped (although mostly informal) lithostratigraphic units within the White River Group (Fig. 3). White River lithostratigraphy has been debated for over a century, but was mostly clarified by Morris Skinner and other workers from the Frick Laboratory starting in the 1930's (Emry et al., 1987). Several intercalated ashes were dated by $\mathrm{K}-\mathrm{Ar}$ methods (Evernden et al., 1964) and a paleomagnetic stratigraphy was established by Prothero et al. (1983) and Prothero (1985a,b). Reanalysis of these ashes and paleomagnetic stratigraphies as well as several additional ashes and paleomagnetic sections with more precise ${ }^{40} \mathrm{Ar} /{ }^{39} \mathrm{Ar}$ and paleomagnetic methods by Swisher and Prothero (1990), Prothero and Swisher (1992), and Evanoff et al. (1992) provides an integrated regional geochronology of the White River Group. This revised framework provides outstanding geochronologic control and is used to assign ages to the fossil teeth (Fig. 4). Ages for samples are assigned by interpolating between ${ }^{40} \mathrm{Ar} /{ }^{39} \mathrm{Ar}$ and magnetic reversal boundaries.

The two oldest horse jaws are from the White River Formation in the North Fork of Lone Tree Gulch section at Flagstaff Rim, Natrona County, Wyoming (Fig. 3; Emry, 1973, 1992). Geochronology is constrained by paleomagnetic stratigraphy and ${ }^{40} \mathrm{Ar} /{ }^{39} \mathrm{Ar}$ dates for several ashes (Fig. 4). One jaw was collected $20 \mathrm{~m}$ below Ash D (F:AM 129117) and the other was collected 27 m above Ash D (F:AM 129116). Ash D was not dated by Swisher and Prothero (1990). The specimens are bracketed by ${ }^{40} \mathrm{Ar} /{ }^{39} \mathrm{Ar}$ dates of $36.0 \mathrm{Ma}$ for the underlying Ash $\mathrm{B}$, and $35.8 \mathrm{Ma}$ for the overlying Ash F. This level is within a long reversed interval correlated with Chron $\mathrm{C} 15 \mathrm{r}$ by Prothero and Swisher (1992), but a correlation with Chron C16n.lr in the Cande and Kent (1992) timescale provides a better agreement between the polarity record and ${ }^{40} \mathrm{Ar} /{ }^{39} \mathrm{Ar}$ dates.

The second suite of samples is from the White River Formation in Niobrara County, Wyoming (Fig. 3). Prothero (1985a, b) and Evanoff et al.
(1992) published paleomagnetic stratigraphies of the Chadron and Brule members from several sections in the area, and chrons $\mathrm{C} 12 \mathrm{r}$ through the top of $\mathrm{C} 16 \mathrm{n}$ are represented. The Persistent White Layer (PWL; also known as the Persistent White Ash, Purplish White Layer, Glory Hole Ash, and Tuff 5 of various authors) is a widely distributed ash dated by ${ }^{40} \mathrm{Ar} /{ }^{39} \mathrm{Ar}$ at $33.9 \mathrm{Ma}$ (Swisher and Prothero, 1990). The PWL marks the boundary of the Chadron and Brule members in the area and is within Chron C13r. Two jaws from the Chadron Member and four from the Brule Member of the White River Formation were analyzed. The stratigraphic position of each sample relative to the PWL is known and the fossils can be placed in the paleomagnetic sections analyzed by Prothero (1985a, b) and by Evanoff et al. (1992).

The third suite of samples is from the Big Badlands of South Dakota (Fig. 3). In the Big Badlands the White River is elevated to group status and the Chadron and Brule are raised to formation rank. An informal lithostratigraphic framework used by Morris Skinner and the Frick Laboratory is shown in Fig. 4. These informal (Lower and Upper Nodular Zones, Middle and Upper Oreodon Beds, and Leptauchenia Nodule Zone) and the formal subdivisions (Scenic and Poleside members) of the Brule Formation formed the lithostratigraphic framework for the paleomagnetic stratigraphy developed by Prothero et al. (1983), Prothero (1985a, b), and Prothero and Swisher (1992). The stratigraphic positions of fossils are also recorded within this framework. The Rockyford Ash (also known as the Nonpareil Ash Zone), dated at $30.1 \mathrm{Ma}$ by ${ }^{40} \mathrm{Ar} /{ }^{39} \mathrm{Ar}$ (Swisher and Prothero, 1990), caps the White River Group in the Big Badlands.

\subsection{Analytical methods}

Enamel from the labial margin (where the enamel is thickest) was cut from the tooth, the dentine drilled away, and enamel powdered and homogenized. $\delta_{\mathrm{p}}$ was determined by an ionexchange, silver phosphate fluorination method (Crowson et al., 1991) and results are reported in standard delta notation relative to SMOW (Craig, 1961). Calcium was determined by flame atomic 


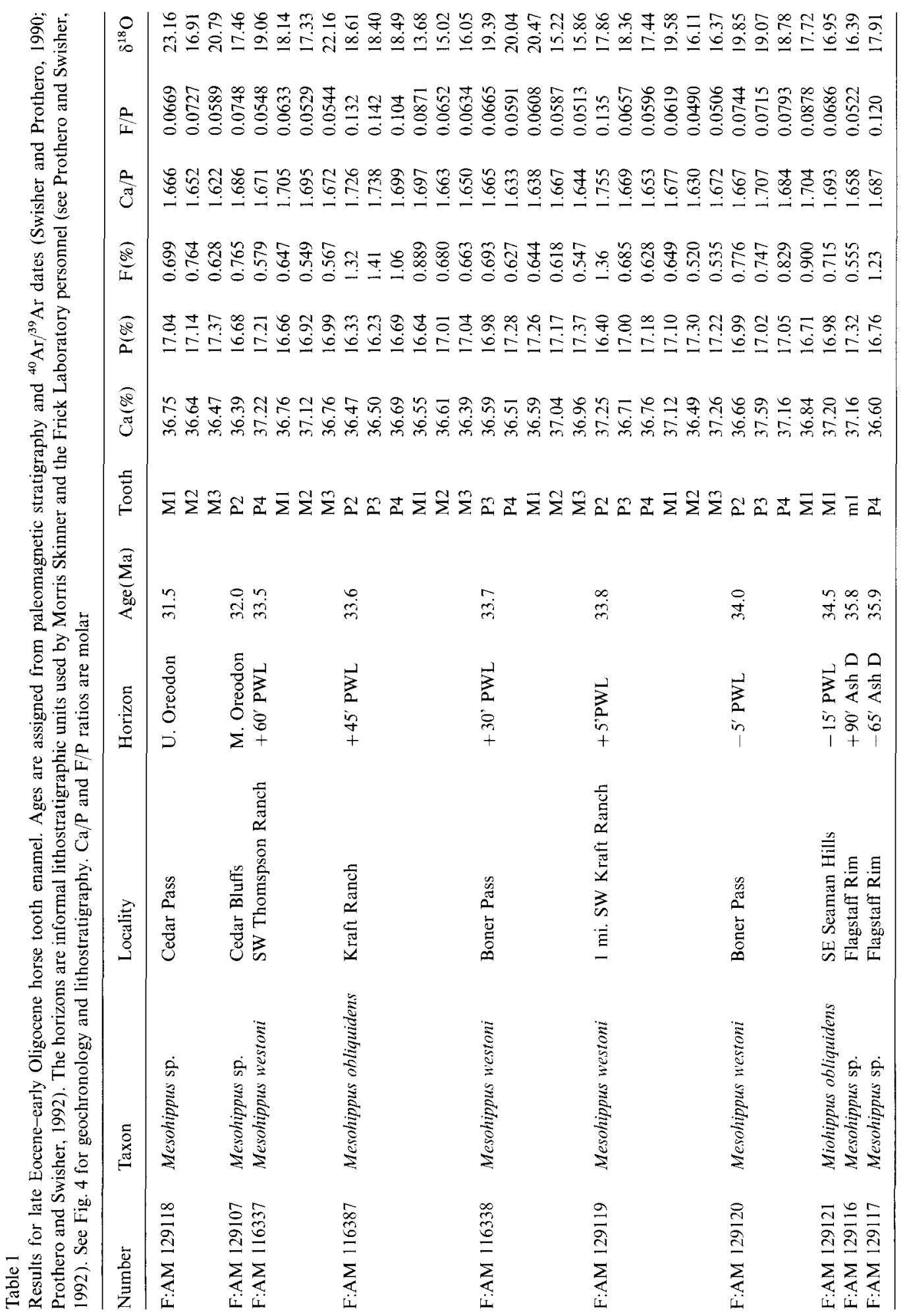




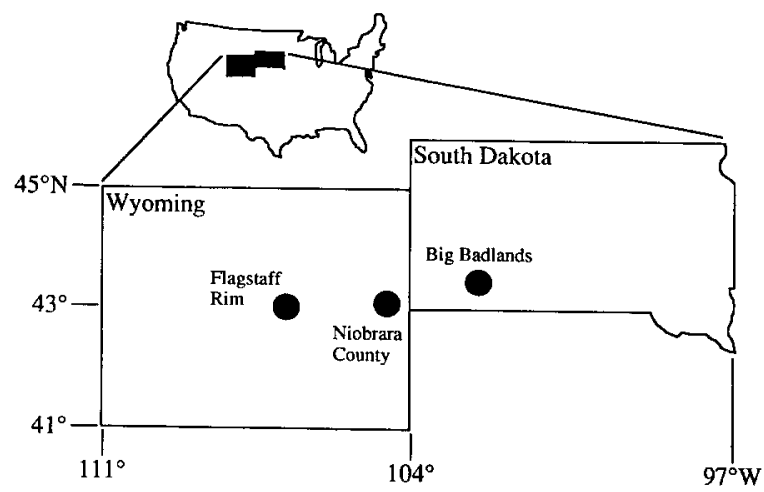

Fig. 3. White River sample localities. The Big Badlands and Niobrara County localities are composites of several different sections located near each other and intercorrelated.

absorption spectroscopy, phosphorus by phosphomolybdate colorimetry, and fluorine by specificion electrode potentiometry. Complete analytical details are presented in Bryant (1995). Analytical precision and accuracy were monitored with two phosphorite rock standards from the National Institute of Technology, SRM-120c and SRM-694 (Table 2). Mineralogy was determined by X-ray diffraction and Fourier-transform infrared spectroscopy.

\section{Results}

Results are presented in Table 1 . The $\mathrm{Ca} / \mathrm{P}$ and $\mathbf{F} / \mathbf{P}$ of Eocene-Oligocene fossil enamel is very different from that of modern horse enamel. The $\mathrm{Ca} / \mathrm{P}$ in modern equid enamel ranges from 1.55 to 1.64 , lower than the stoichiometric ratio of 1.67 (Bryant, 1995). The $\mathrm{Ca} / \mathrm{P}$ ratio in EoceneOligocene enamel ranges from 1.62 to 1.76 . Similarly, the F/P ratio of fossil enamel ranges from 0.05 to 0.14 , at least an order of magnitude higher than in modern enamel. These ranges are similar to those reported elsewhere for fossil enamel (Parker et al., 1974; Bryant, 1995).

There are three distinctive patterns in the $\delta_{\mathrm{P}}$ of individual teeth within a jaw (Fig. 5). Two of these are similar to patterns found in Miocene fossil equids (Bryant et al., 1996), termed Pattern 1 and Pattern 2. In Pattern 1 the $\delta_{\mathrm{p}}$ pattern among the individual teeth, plotted in sequence of eruption, has a concave-up shape and $\delta_{\mathrm{P}}$ of $\mathrm{M} 1$ and $\mathrm{M} 3$ is generally higher than that of other teeth in the jaw (Fig. 5). In Pattern 2 the $\delta_{\mathrm{P}}$ pattern has a concavedown shape and $\delta_{\mathrm{P}}$ of M1 and M3 is generally lower than that of other teeth in the jaw. There is a third pattern in the Eocene-Oligocene equid jaws, but this pattern is different from that termed Pattern 3 in the Miocene horses (Bryant et al., 1996). We therefore term this Pattern 4, to differentiate it from Pattern 3 found in Miocene horses. In Pattern 4 the $\delta_{\mathrm{P}}$ of $\mathrm{M} 1$ is higher than that of the other teeth (as in Pattern 1), but results for the rest of the teeth have a concave-down pattern similar to Pattern 2 (Fig. 5). When plotted together, the results for individual jaws are divergent in the $\delta_{\mathrm{P}}$ of the M1 and M3 (Fig. 6), which are the first and last permanent teeth to mineralize, respectively. The $\delta_{\mathrm{P}}$ of M2 through $\mathrm{P} 4$ is comparable among the individual jaws.

\section{Discussion}

\subsection{Patterns in $\delta_{P}$ along the toothrow}

The intrajaw $\delta_{\mathbf{P}}$ patterns are interpreted to reflect the timing of enamel mineralization and the season of birth, similar to results and interpretations for modern and Miocene horses (Bryant et al., 1996) and modern sheep and a $\sim 500$-year old bison (Fricke and O'Neil, 1996). However, because Mesohippus and Miohippus had much smaller body size and more brachydont dentition than the modern and Miocene horses, the timing of mineralization may have been relatively accelerated. The $\delta_{\mathrm{p}}$ patterns in the jaws of Mesohippus and Miohippus, therefore, are expected to be different from patterns observed in Miocene and modern jaws of horses born in the same season.

Bryant et al. (1996) modify the body water model from Bryant and Froelich (1995) to include growth, nursing, and season of birth for a foal to determine how these factors control the $\delta_{\mathrm{P}}$ patterns observed in modern and Miocene horse jaws. The $\delta^{18} \mathrm{O}$ of body water follows a seasonal cycle similar to the annual cycle observed in $\delta^{18} \mathrm{O}$ of precipitation (Rozanski et al., 1993). Because the enamel mineralization sequence is known, individual teeth 


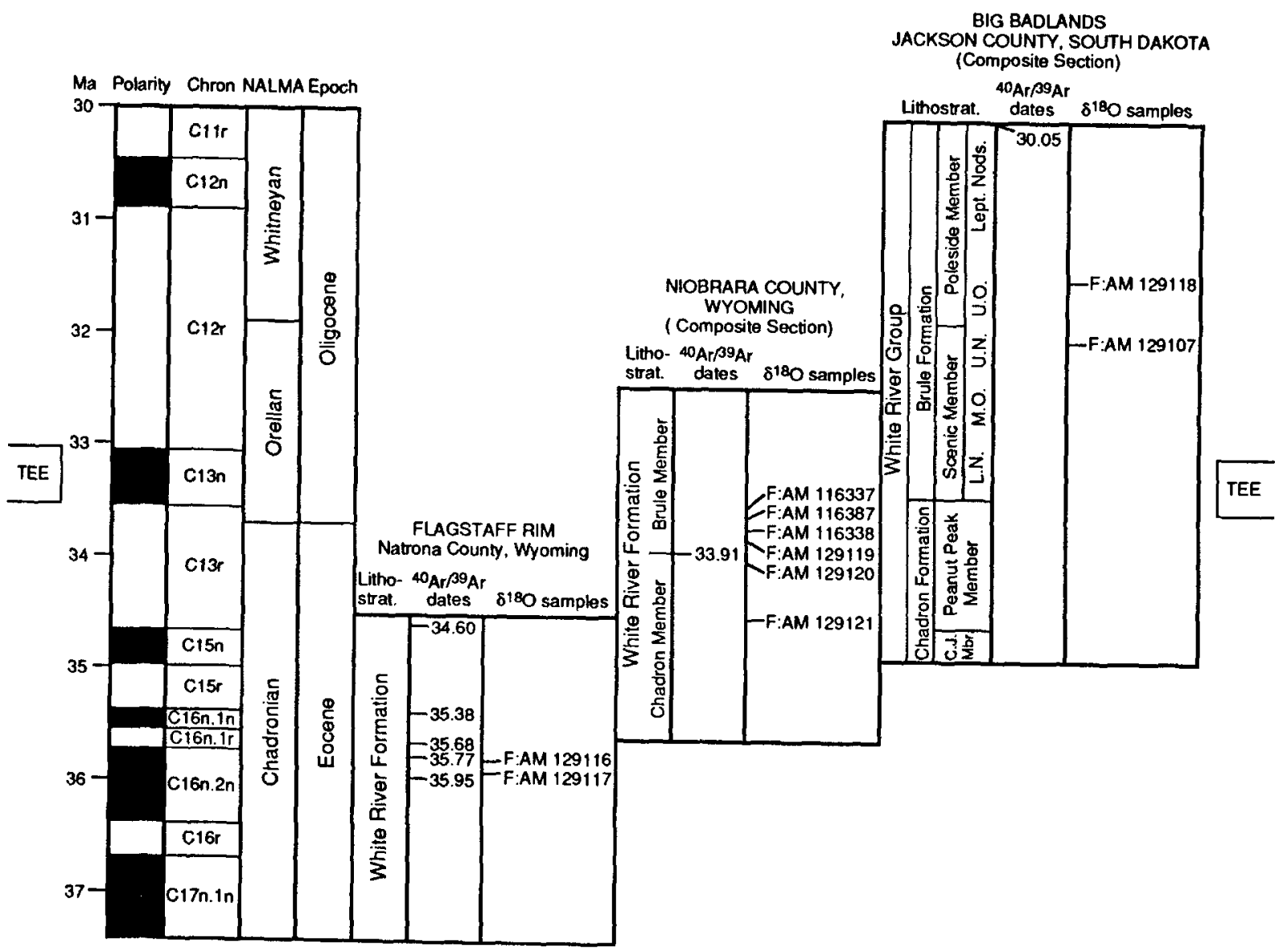

Fig. 4. Geochronology of the late Eocene-early Oligocene White River localities. The geomagnetic polarity timescale is after Cande and Kent (1992). The intercorrelation of sections, correlation to the geomagnetic polarity timescale, North American land mammal ages (NALMA), and ${ }^{40} \mathrm{Ar} /{ }^{39} \mathrm{Ar}$ dates are from Swisher and Prothero (1990), Prothero and Swisher (1992), and Evanoff et al. (1992). Lithostratigraphic subdivisions below member status for the Brule Formation in the Big Badlands follows an informal zonation used by M.F. Skinner, as published by Prothero and Swisher (1992), with the following abbreviations: $L . N$. = lower nodule zone; U.N.= upper nodule zone; $M . O .=$ middle Oreodon beds; $U . O .=$ upper Oreodon beds; Lept. Nods. $=$ Leptauchenia nodule zone. The stratigraphic rank and subdivisions of the White River Formation or Group varies between localities (see text). The Terminal Eocene Event $(T E E)$ occurs in marine records during Chron $\mathrm{C} 13 \mathrm{n}$ in the early Oligocene and is thought to be contemporaneous in terrestrial environments.

from a jaw can be superimposed, in mineralization sequence, on the seasonal $\delta^{18} \mathrm{O}$ cycle. The exact age at which mineralization occurs is not known a priori; the timing (but not sequence) of mineralization of each tooth can therefore be adjusted along the seasonal $\delta^{18} \mathrm{O}$ cycle so that the resulting pattern in $\delta_{\mathrm{P}}$ fits the patterns observed in the fossil jaws. Season of birth and timing of tooth mineralization can then be interpreted from the observed patterns and $\delta_{\mathbf{P}}$ fit with a modeled seasonal cycle.
A seasonal cycle in $\delta^{18} \mathrm{O}$ of body water is modeled with a harmonic motion equation and takes the form of a cosine wave (Fig. 7; Bryant et al., 1996), an approximation of the seasonal variation observed in modern precipitation (Rozanski et al., 1993). Pattern 1 (Fig. 7a) can be derived for a foal born in the spring with mineralization of the teeth accomplished in about one year. This is the same birth season interpreted for Pattern 1 in the Miocene horses (Bryant et al., 
Table 2

Comparison of analytical results from this study with certified values for two phosphorite rock standards from the National Institute of Standards and Technology (NIST). Uncertainties are $\pm 2 \sigma$. Abbreviations: $n . c .=$ not certified; $n . d .=$ not determined

\begin{tabular}{lllll}
\hline Measurement & $\begin{array}{l}\text { SRM 120c } \\
\text { (certified) }\end{array}$ & $\begin{array}{l}\text { SRM 120c } \\
\text { (this study) }\end{array}$ & $\begin{array}{l}\text { SRM 694 } \\
\text { (certified) }\end{array}$ & $\begin{array}{l}\text { SRM 694 } \\
\text { (this study) }\end{array}$ \\
\hline Ca (weight \%) & $34.32 \pm 0.10$ & $34.10 \pm 0.58(n=14)$ & $31.2 \pm 0.3$ & $30.55 \pm 0.58(n=7)$ \\
P (weight \%) & $14.55 \pm 0.03$ & $14.49 \pm 0.20(n=10)$ & $13.2 \pm 0.1$ & $13.23 \pm 0.28(n=7)$ \\
F (weight \%) & $3.82 \pm 0.02$ & $3.86 \pm 0.12(n=10)$ & $3.2 \pm 0.1$ & $3.18 \pm 0.14(n=10)$ \\
$\delta^{18}$ O (\%oSMOW) & $21.33 \pm 0.10^{a}$ & $21.36 \pm 0.36(n=13)$ & n.c. & n.d. \\
\hline
\end{tabular}

${ }^{a} \delta^{18} \mathrm{O}$ is not certified by NIST. This result is quoted by Crowson et al. (1991) ( $\left.n=15\right)$. Barrick and Showers (1994) quote a precision of $\pm 0.14 \%(2 \sigma)$.

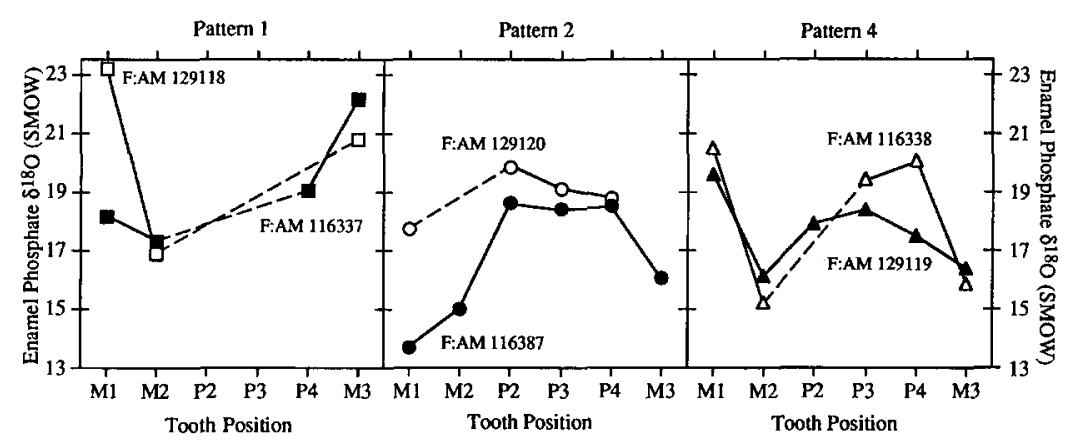

Fig. 5. Patterns of variation in $\delta^{18} \mathrm{O}$ of tooth enamel from late Eocene-early Oligocene horses. Tooth position follows the mineralization sequence (Fig. 2). Pattern 1 has a concave up shape, and $\delta^{18} \mathrm{O}$ of the $\mathrm{M} 1$ and $\mathrm{M} 3$ is generally higher than that of the other teeth, as also observed in modern and Miocene equids (Bryant et al., 1996). Pattern 1 likely represents a spring season birth. Pattern 2 has a concave down shape opposite to that of Pattern 1, and likely represents a fall season birth. A third pattern is termed Pattern 4, to differentiate it from Pattern 3 observed in Miocene horses (Bryant et al., 1996). Pattern 4 has elements of both Pattern 1 and 2: $\delta^{18} \mathrm{O}$ of $\mathrm{M} 1$ is generally higher than the other teeth, but $\delta^{18} \mathrm{O}$ of the other the cheek teeth has a concave down pattern similar to Pattern 2. Pattern 4 likely reflects a spring season birth with ontogenetically-delayed mineralization.

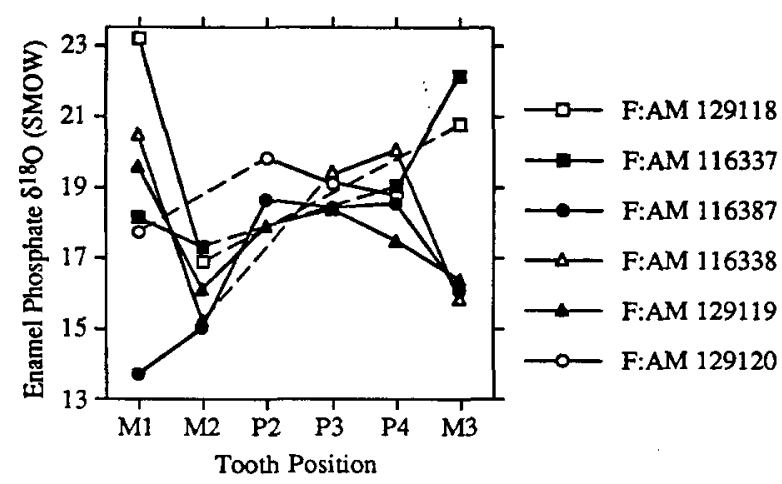

Fig. 6. Comparison of results and $\delta^{18} \mathrm{O}$ patterns found in White River equid jaws. Teeth are shown in the order of mineralization, not the order in the jaw. The $\delta^{18} \mathrm{O}$ of the M1 and M3 is very divergent in all three patterns, but $\delta^{18} \mathrm{O}$ of the $\mathrm{M} 2$ and premolars is very similar among the jaws.
1996). However, Pattern 1 in the EoceneOligocene horses is more concave $\left(\delta_{\mathrm{p}}\right.$ of $\mathrm{M} 1$ and M3 is higher than that of the other cheek teeth) than in the modern and Miocene horses; thus mineralization must have began earlier and was completed quicker than in the modern horses, probably within one year. In the Miocene and modern horses with Pattern 1 (spring birth), on the other hand, $\delta_{\mathrm{p}}$ of $\mathrm{M} 1$ is high and $\delta_{\mathrm{p}}$ of $\mathrm{M} 3$ is either similar to that of the other cheek teeth or only slightly higher. The individual cheek teeth mineralize over 6-12 months, and mineralization of all of the permanent teeth occurs over a period of 2.5-3 years (Bryant et al., 1996). The resulting $\delta_{\mathrm{p}}$ pattern is relatively flat for the intermediate teeth in the eruption sequence (M2 and P2-3), slightly different from the patterns in Mesohippus and Miohippus. 


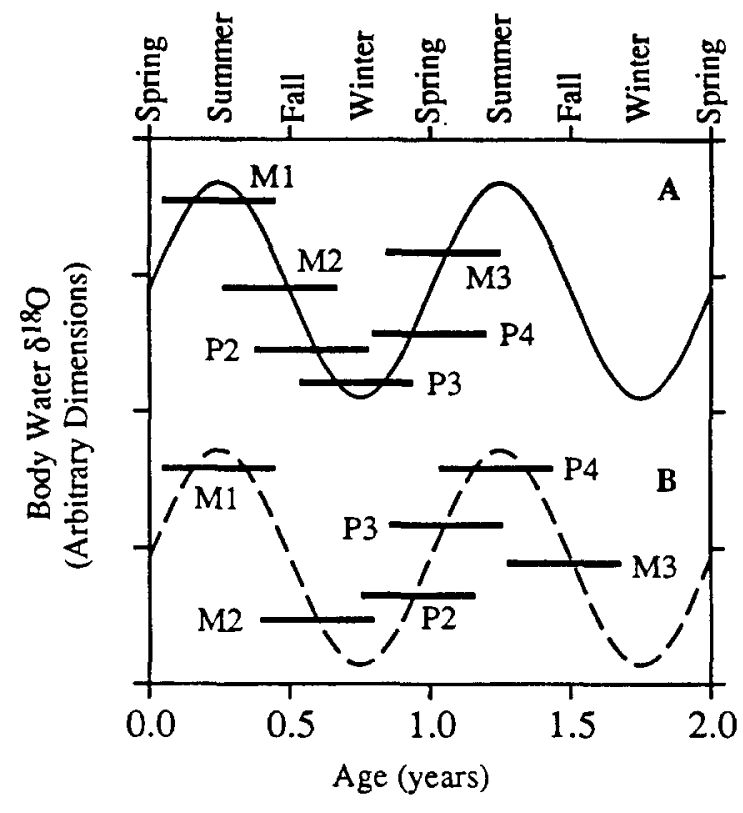

Fig. 7. A,B. Interpretation of intrajaw patterns in enamel $\delta^{18} \mathrm{O}$. See Fig. 5 for examples of the enamel $\delta^{18} \mathrm{O}$ patterns. $\delta^{18} \mathrm{O}$ of environmental water undergoes a seasonal cycle that is reflected by the $\delta^{18} \mathrm{O}$ of body water of horses (Bryant et al., 1996). The timing of tooth mineralization (dark horizontal bars) is superimposed on a typical seasonal cycle (modeled as a cosine wave) to understand how the different patterns in enamel $\delta^{18} \mathrm{O}$ may be derived. The $\delta^{18} \mathrm{O}$ of enamel represents an integrated average of the $\delta^{18} \mathrm{O}$ (offset for equilibrium precipitation at $37^{\circ} \mathrm{C}$ ) of body water during the mineralization interval. A (solid line), Pattern 1 is interpreted to represent a spring season birth with full mineralization of all of the teeth within one year. Pattern 2 is the exact opposite of Pattern 1, indicating a fall season birth (enamel mineralization is shifted by 6 months). B (dashed line), Pattern 4 is interpreted to represent spring season birth, but mineralization is delayed and occurs over a 1.5 year period.

Pattern 2 in the Eocene-Oligocene horses, as in Pattern 2 in the Miocene and modern horses, represents fall-season birth. The $\delta_{\mathrm{P}}$ pattern is the opposite of Pattern 1 (Fig. 7b). Modern zebras and feral horses have distinctive breeding peaks and approximately $75 \%$ of the foals are born in the spring, although foaling can occur at any time during the year (Smuts, 1976; Berger, 1986). Of the six Eocene-Oligocene horse jaws from which several teeth were measured, results for two have Pattern 2. Although a sample size of six jaws is not sufficiently large to test for statistical signifi- cance, one possible interpretation is that the fossil equids did not have a highly seasonal birth cycle. If, in contrast, birth was highly seasonal in a population, then birth would probably be timed to coincide with the spring season, and Pattern 2 would not be commonly represented. Pattern 1 or a variant (like Pattern 4; see below) would be most expected. A similar result (relatively nonseasonal birth cycle) was found in Miocene horses (Bryant et al., 1996). These ancient horses apparently probably did not have highly seasonal birth cycles, possibly indicative of paleoclimates with less seasonal variability.

Pattern 4 in the Eocene-Oligocene horses does not have an analog in Miocene or modern horses. The most reasonable interpretation of Pattern 4 is a spring birth, as in Pattern 1, indicated by the relatively high $\delta_{\mathrm{p}}$ of Ml (Fig. 5). However, to generate the pattern observed in $\delta_{\mathrm{P}}$ of $\mathrm{M} 2-\mathrm{M} 3$, enamel mineralization must have occurred slightly slower, or was ontogenetically delayed, relative to Pattern 1. The additional time over which mineralization occurred is not long. Only about 6 additional months ( 1.5 years total mineralization time) are necessary, which is within the natural range of variation observed in timing of mineralization and eruption in modern horses and other large mammals (Hillson, 1986). Thus it appears there was diversity in both the season of birth and the time period over which mineralization occurs. Five of the six jaws analyzed and shown in Fig. 5 are Mesohippus, so it is not possible to determine if there are correlations between the season of birth or timing of mineralization and the systematics of the late Eocene-early Oligocene fossil horses or within a time series.

\subsection{Diagenesis}

One advantage of using $\delta_{\mathrm{P}}$ for paleobiologic and paleoclimatic reconstruction is the resistance of the phosphate-oxygen to isotopic exchange in the sedimentary environment. Pervasive diagenesis and recrystallization of enamel results in a transition from biogenic hydroxylapatite to carbonate fluorapatite (Bryant, 1995). This transition is accompanied by a sharp increase in the $F / P$ ratio and a smaller increase in the $\mathrm{Ca} / \mathrm{P}$ ratio of the enamel. 
There are no heavily altered samples among the Eocene-Oligocene teeth (Fig. 8). All of the teeth retain a hydroxylapatite mineralogy, although there are five samples with higher $\mathrm{F} / \mathrm{P}$ ratios than the other teeth. This indicates diagenesis has affected these samples to some degree. However, the resulting diagenetic trend does not result in a strong offset in $\delta_{\mathrm{P}}$ relative to the unaltered teeth. The Eocene-Oligocene teeth appear to be transforming towards the same $\delta_{\mathrm{P}}$ and $\mathrm{F} / \mathrm{P}$ field defined by heavily recrystallized Miocene fossil teeth. The primary $\delta_{\mathrm{P}}$ signal, however, does not appear to be compromised. In addition to the conversion to carbonate fluorapatite with associated increases in $\mathrm{F} / \mathrm{P}$ and $\mathrm{Ca} / \mathrm{P}$, pervasive diagenesis is expected to homogenize the trend in $\delta_{\mathrm{P}}$ along the toothrow due to recrystallization of all of the teeth at lower temperatures in equilibrium with water with lower $\delta^{18} \mathrm{O}$ (Bryant, 1995). This is not observed in the Eocene-Oligocene teeth. The two jaws whose teeth have the highest $\mathrm{F} / \mathrm{P}$ ratio ( $\mathrm{F}: \mathrm{AM} 116387$ and $F: A M ~ 129119)$ preserve very clear $\delta_{P}$ patterns (Fig. 5).

\subsection{Implications for reconstruction of continental climate}

As outlined above, the Terminal Eocene Event is one of the most abrupt climate shifts in the Cenozoic and there is clear evidence for climatic and ecologic change in the White River Group. $\delta_{\mathrm{P}}$ of fossil equid teeth may provide a record of this shift. However, simply plotting a time series of $\delta_{\mathrm{P}}$ results without considering tooth position or intrajaw $\delta_{\mathbf{P}}$ pattern would be very misleading. Rather, each tooth position from each intrajaw pattern must be considered individually. Simply stated, the different teeth, in the different patterns, mineralize at different times (seasons) of the year, and hence the $\delta_{\mathrm{P}}$ of individual teeth will record different seasonal influences. If the intrajaw $\delta_{\mathbf{p}}$ patterns are ignored or unknown, variation within the jaw due to seasonal and ontogenetic influences will obscure any evidence of paleoclimatic change.

The season represented by individual teeth in each intrajaw pattern can be interpreted from the observed patterns with seasonal variation in $\delta^{18} \mathrm{O}$ of precipitation (Fig. 7). The M1 represents the summer season in patterns 1 and 4, and the winter season in Pattern 2 (Table 3). The seasonal differences between teeth from jaws with Pattern 1 are direct opposites to those with Pattern 2. Teeth from jaws with Pattern 4 have different mineralization times out of phase with the other jaws. Recognition of these seasonal differences complicates climate reconstruction if only individual teeth

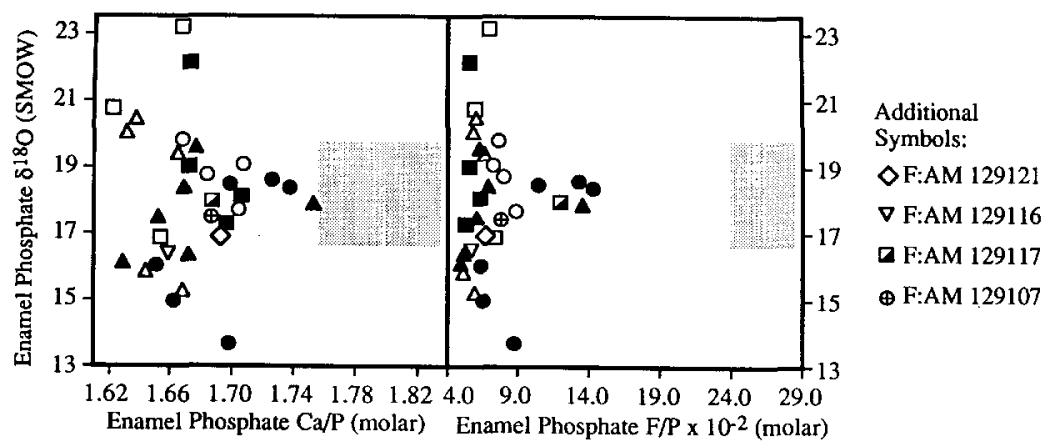

Fig. 8. Diagenetic trends in late Eocene-early Oligocene equid enamel. $\mathrm{Ca} / \mathrm{P}$ and $\mathrm{F} / \mathrm{P}$ are sensitive to recrystallization of hydroxylapatite to carbonate fluorapatite, accompanied by reprecipitation in equilibrium with sedimentary conditions very different from in vivo conditions. The stippled regions are the ranges observed in heavily recrystallized Miocene equid enamel from Nebraska (Bryant, 1995), which seem to also represent the diagenetically-altered end member towards which the late Eocene-early Oligocene tooth enamel is transforming. There are shifts towards the recrystallized region, but the preservation of a hydroxylapatite mineralogy by the enamel, low F/P ratios relative to the heavily recrystallized samples, and presence of characteristic patterns in $\delta^{18} \mathrm{O}$ along the toothrow indicate that a primary $\delta^{18} \mathrm{O}$ signal is preserved. 
Table 3

Relative seasons at which different teeth mineralize for each intrajaw $\delta_{\mathbf{p}}$ pattern found in late Eocene-early Oligocene Mesohippus and Miohippus jaws from the White River Group. Seasonal assignments are based on intrajaw patterns of enamel mineralization (Fig. 7), and are only intended in a general sense

\begin{tabular}{llll}
\hline \multicolumn{4}{c}{ Intrajaw $\delta_{\mathrm{P}}$ pattern } \\
\cline { 2 - 4 } Tooth position & 1 & 2 & 4 \\
\hline M1 & Summer & Winter & Summer \\
M2 & Fall & Spring & Late Fall \\
P2 & Late Fall & Late Spring & Spring \\
P3 & Winter & Summer & Late Spring \\
P4 & Spring & Fall & Summer \\
M3 & Summer & Winter & Fall \\
\hline
\end{tabular}

or a few jaws are available. However, these different patterns may allow changes in seasonal temperatures (i.e., warmer summers and cooler winters) to be reconstructed. Furthermore, if there are two or more different intrajaw patterns in $\delta_{\mathrm{p}}$, then climate reconstructions from jaws with different patterns can be compared to determine if they are consistent. Thus unlike many climate proxies that rely on a single time series, the possibility exists to reconstruct seasonal climate changes and have two or more proxies of the same climate record.

A final factor to consider is the possible influence of nursing and weaning during the mineralization period. In modern equids, only the M1 and M2 mineralize before or during the weaning period, and hence only their $\delta_{\mathbf{p}}$ should be influenced by nursing. Nursing affects $\delta_{\mathrm{p}}$ because the $\delta^{18} \mathrm{O}$ of water and metabolic oxygen derived from mare's milk is offset from the $\delta^{18} \mathrm{O}$ of ingested water and plant matter from grazing or browsing sources. There is no clear evidence in tooth enamel $\delta_{\mathrm{p}}$ for age of weaning in Mesohippus and Miohippus. Age at weaning, in general, also increases with increasing body size, but ecology strongly influences the precise timing and there is considerable variation in the age of weaning among modern equids (Becker and Ginsberg, 1990). Thus although the teeth mineralized much earlier in Mesohippus and Miohippus, the animals were probably also weaned earlier. The permanent teeth that mineralize earliest (M1 and M2) most likely formed before or during weaning. The teeth that form in the intermediate stages of the sequence ( $\mathrm{P} 2$ and $\mathrm{P} 3$ ) may possibly record some nursing effects. Perhaps the best approach to this problem, therefore, is to use the permanent teeth that mineralize last ( $\mathrm{P} 4$ and M3) for climate reconstruction.

\section{Conclusions}

Because of the different intrajaw $\delta_{\mathrm{P}}$ patterns and small number of fossil jaws analyzed in this study, a paleoclimate reconstruction from the White River equid $\delta_{\mathrm{P}}$ results would be very premature. It is clear, however, that $\delta_{\mathrm{P}}$ of fossil enamel may provide new insight into the biology of extinct species and may also provide a very sensitive record of ancient climate in future studies. In addition to the late Eocene-early Oligocene equids, patterns of variation in enamel $\delta_{\mathrm{P}}$ are now also known for modern horses, sheep, and bison, and Miocene horses (Bryant et al., 1996; Fricke and O'Neil, 1996). The $\delta_{\mathrm{p}}$ of tooth enamel from late Eocene-early Oligocene horse teeth (Miohippus and Mesohippus) from the White River Group in the western Great Plains preserves evidence of the season of birth and the ontogeny of tooth enamel mineralization. Birth was apparently concentrated in the spring season, but does not appear to have been highly seasonal because results for two of the six jaws measured have patterns indicative of fall-or winter-season birth. Enamel mineralization of all six cheek teeth in the fossil equid jaws must have been complete after 1-1.5 years. Although there is evidence of post-depositional alteration in the $\mathrm{Ca} / \mathrm{P}$ and $\mathrm{F} / \mathrm{P}$ ratios of the enamel, the enamel is composed of hydroxylapatite, is chemically distinct from the diagenetic signal observed in Miocene tooth enamel, and $\delta_{\mathrm{P}}$ of individual teeth within the same jaw show distinctive, biological variation patterns. Pervasive recrystallization and reprecipitation under different oxygen isotopic equilibrium conditions, therefore, do not appear to be significant problems in these teeth.

$\delta_{\mathbf{p}}$ of fossil mammalian tooth enamel has great promise in continental paleoclimate reconstruction. However, it is clear from this analysis that $\delta_{\mathrm{P}}$ paleoclimatology using horse teeth will not be 
straightforward. Analysis of a single time series of teeth, without considering the tooth position or season of mineralization, clearly is not a good approach. Rather, a time series of jaws, with different intrajaw $\delta_{\mathrm{P}}$ patterns, is the best approach to the problem. Analyzing teeth from a series of jaws has the advantages that (1) changes in seasonal climate regimes can be reconstructed, and (2) more than one proxy will record the same season and interval of time. The disadvantage of this approach is the large number of samples required. Currently, the only paleoclimate proxy that provides such detailed information is leaf physiognomy (Wolfe, 1993). Fossil mammals are much more widely distributed in time and space than fossil floras sufficiently well preserved for leaf physiognomy, and thus have the potential to greatly increase our knowledge of continental climate change. Unrecognized biological fractionation effects still remain to be discovered. Such effects could provide new paleobiological information for ancient species.

\section{Acknowledgements}

We thank L. Baker, M. Collinson, R. Emry, R. Evander, G. Harlow, J. Hooker, A. Ingalls, T. Jones, D. Kent, P. Koch, E. Lindars, P. Malone, M. McKenna, R. Mortlock, P. Olsen, J. O'Neil and $\mathrm{R}$. Tedford for their help with this research. This study would not have been possible without the detailed field notes and collections made by Frick Laboratory personnel, especially the late M.F. Skinner. The following organizations provided funds in support of this research: Paleontological Society, Geological Society of America, Lamont-Doherty Earth Observatory Climate Center, Sigma Xi, Graduate Faculty Alumni of Columbia University, and NSF grants EAR 91-14083 and EAR 92-19108.

\section{References}

Ayliffe, L.K., Lister, A.M. and Chivas, A.R., 1992. The preservation of glacial-interglacial climatic signatures in the oxygen isotopes of elephant skeletal phosphate. Palaeogeogr. Palaeoclimatol. Palaeoecol., 99: 179-191.

Ayliffe, L.K., Chivas, A.R. and Leakey, M.G., 1994. The retention of primary oxygen isotope compositions of fossil elephant skeletal phosphate. Geochim. Cosmochim. Acta, 58: 5291-5298.

Barrick, R.E. and Showers, W.J., 1994. Thermophysiology of Tyrannosaurus rex: Evidence from oxygen isotopes. Science, 265: 222-224.

Becker, C.D. and Ginsberg, J.R., 1990. Mother-infant behaviour of wild Grevy's zebra: adaptations for survival in semidesert East Africa. Anim. Behav., 40: 1111-1118.

Berger, J., 1986. Wild Horses of the Great Basin. Univ. Chicago Press, Chicago, 326 pp.

Blueweiss, L., Fox, H., Kudzma, V., Nakashima, D., Peters, R. and Sams, S., 1978. Relationships between body size and some life history parameters. Oecologia, 37: 257-272.

Bryant, J.D., 1995. Oxygen isotope systematics in mammalian body water and in modern and fossil equid tooth enamel phosphate. Thesis. Columbia Univ., New York.

Bryant, J.D. and Froelich, P.N., 1995. A model of oxygen isotope fractionation in body water of large mammals. Geochim. Cosmochim. Acta, 59: 4523-4537.

Bryant, J.D., Froelich, P.N., Showers, W.J. and Genna, B.J., 1996. A tale of two quarries: biologic and taphonomic signatures in the oxygen isotopic composition of tooth enamel phosphate from modern and Miocene equids. Palaios, 11, in press.

Bryant, J.D., Luz, B. and Froelich, P.N., 1994. Oxygen isotopic composition of fossil horse tooth phosphate as a record of continental paleoclimate. Palaeogeogr. Palaeoclimatol. Palaeoecol., 107: 303-316.

Cande, S.N. and Kent, D.V., 1992. A new geomagnetic polarity time scale for the late Cretaceous and Cenozoic. J. Geophys. Res., 97: 13,917-13,951.

Clark, J., Beerbower, J.R. and Kietzke, K.K., 1967. Oligocene sedimentation, stratigraphy, paleoecology, and paleoclimatology in the Big Badlands of South Dakota. Fieldiana Geol. Mem., 5: 1-158.

Craig, H., 1961. Standard for reporting concentrations of deuterium and oxygen-18 in natural waters. Science, 133: 1833-1834.

Crowell-Davis, S.L., Houpt, K.A. and Carnevale, J., 1985. Feeding and drinking behavior of mares and foals with free access to pasture and water. J. Anim. Sci., 60: 883-889.

Crowson, R.A., Showers, W.J., Wright, E.K. and Hoering, T.C., 1991. Preparation of phosphate samples for oxygen isotope analysis. Anal. Chem., 63: 2397-2400.

D'Angela, D., 1991. Gli isotopi dell'ossigeno come informatori paleoclimatici: alcuni dati sperimentali. Natura Bresciana (Ann. Mus. Civ. Sci. Nat. Brescia), 26: 331-337.

D'Angela, D. and Longinelli, A., 1993. Oxygen isotopic composition of fossil mammal bones of Holocene age: Palaeoclimatological considerations. Chem. Geol. (Isot. Geosci. Sect.), 103: 171-179.

Emry, R.J., 1973. Stratigraphy and preliminary biostratigraphy 
of the Flagstaff Rim area, Natrona County, Wyoming. Smithson. Contrib. Paleobiol., 18: 1-43.

Emry, R.J., 1992. Mammalian range zones in the Chadronian White River Formation at Flagstaff Rim, Wyoming. In: D.R. Prothero and W.A. Berggren (Editors), Eocene-Oligocene Climatic and Biotic Evolution. Princeton Univ. Press, Princeton, pp. 106-115.

Emry, R.J., Russell, L.S. and Bjork, P.R., 1987. The Chadronian, Orellan, and Whitneyan North American land mammal ages. In: M.O. Woodburne (Editor), Cenozoic Mammals of North America: Geochronology and Biostratigraphy. Univ. Calif. Press, Berkeley, pp. 118-152.

Erz, W., 1964. Tooth eruption and replacement in Burchell's zebra, Equus burchelli Gray 1825. Arnoldia, 1(22): 1-8.

Evanoff, E., Prothero, D.R. and Lander, R.H., 1992. Eocene Oligocene climatic change in North America: The White River Formation near Douglas, east central Wyoming. In: W.A. Berggren and D.R. Prothero (Editors), Eocene-Oligocene Climatic and Biotic Evolution. Princeton Univ. Press, Princeton, pp. 116-130.

Evernden, J.F., Savage, D.E., Curtis, G.H. and James, G.T., 1964. Potassium argon dates and the Cenozoic mammalian chronology of North America. Am. J. Sci., 262: 145-198.

Fricke, H.C. and O'Neil, J.R., 1996. Inter- and intra-tooth variation in the oxygen isotope composition of mammalian tooth enamel: Some implications for paleoclimatological and paleobiological research. Palaeogeogr. Palaeoclimatol. Palaeoecol., 126: 91-99.

Hillson, S., 1986. Teeth. Cambridge Univ. Press, Cambridge, $376 \mathrm{pp}$.

Hulbert Jr., R.C., 1984. Paleoecology and population dynamics of the early Miocene (Hemingfordian) horse Parahippus leonensis from the Thomas Farm site, Florida. J. Vertebr. Paleontol., 4: 547-558.

Hutchison, J.H., 1992. Western North American reptile and amphibian record across the Eocene/Oligocene boundary and its climatic implications. In: D.R. Prothero and W.A. Berggren (Editors), Eocene-Oligocene Climatic and Biotic Evolution. Princeton Univ. Press, Princeton, pp. 451-463.

Janis, C.M., 1989. A climatic explanation for patterns of evolutionary diversity in ungulate mammals. Palaeontology, 32: 463-481.

Janis, C.M., 1990. The correlation between diet and dental wear in herbivorous mammals, and its relationship to the determination of diets of extinct species. In: A.J. Boucot (Editor), Evolutionary Paleobiology of Behavior and Coevolution. Elsevier, Amsterdam, pp. 241-259.

Janis, C.M., 1993. Tertiary mammal evolution in the context of changing climates, vegetation, and tectonic events. Ann. Rev. Ecol. Syst., 24: 467-500.

Lee Thorp, J.A. and Van der Merwe, N.J., 1991. Aspects of the chemistry of modern and fossil biological apatite. J. Archaeol. Sci., 18: 343-354.

Levine, B.M., 1982. The use of crown height measurements and eruption wear sequences to age horse teeth. In: B. Wilson et al. (Editors), Ageing and Sexing Animal Bones from Archaeological Sites. Br. Archaeol. Rep. Ser., 109: 223-250.
Longinelli, A., 1974. Preliminary oxygen isotope measurements of phosphate from mammal teeth and bones. In: J. Labeyrie (Editor), Les Méthodes Quantitative d'Étude des Variations du Climat au cours du Pléistocene. Colloq. Int. CNRS, 219: 267-271.

Luz, B., Kolodny, Y. and Horowitz, M., 1984. Fractionation of oxygen isotopes between mammalian bone phosphate and environmental drinking water. Geochim. Cosmochim. Acta, 48: 1689-1693.

MacFadden, B.J., 1986. Fossil horses from "Eohippus" (Hyra(otherium) to Equus: Scaling, Cope's Law, and the evolution of body size. Paleobiology, 12; 355-369.

MacFadden, B.J., 1992. Fossil Horses: Systematics, Paleobiology, and Evolution of the Family Equidae. Cambridge Univ. Press, Cambridge, 369 pp.

Miller, K.G., 1992. Middle Eocene to Oligocene stable isotopes, climate, and deep water history: The Terminal Eocene Event? In: D.R. Prothero and W.A. Berggren (Editors), EoceneOligocene Climatic and Biotic Evolution. Princeton Univ. Press, Princeton, pp. 160-177.

Parker, R.B., Murphy, J.W. and Toots, H., 1974. Fluorine in fossilized bone and tooth: distribution among skeletal tissues. Archaeometry, 16: 98-102.

Penzhorn, B.L., 1982. Age determination in Cape mountain zebra Equus zebra in the Mountain Zebra National Park Koedoe, 25: 89-102.

Prothero, D.R., 1985a. Chadronian (early Oligocene) magnetostratigraphy of eastern Wyoming: implications for the Eocene-Oligocene boundary. J. Geol., 93: 555-565.

Prothero, D.R., 1985b. Correlation of the White River Group by magnetostratigraphy. In: J.E. Martin (Editor), Fossiliferous Cenozoic Deposits of Western South Dakota and Northwestern Nebraska. Dakoterra, Mus. Geol., South Dakota School Mines, 2: 265-276.

Prothero, D.R., 1989. Stepwise extinctions and climatic decline during the later Eocene and Oligocene. In: S.K. Donovan (Editor), Mass Extinctions: Processes and Evidence. Columbia Univ. Press, New York, pp. 217-234.

Prothero, D.R., 1994. The late Eocene-Oligocene extinctions. Ann. Rev. Earth Planet. Sci, 22: 145-165.

Prothero, D.R. and Shubin, N., 1989. The evolution of Oligocene horses. In: D.R. Prothero and R.M. Schoch (Editors), The Evolution of Perissodactyls. Oxford Univ. Press, New York, pp. 142-175.

Prothero, D.R. and Swisher III, C.C., 1992. Magnetostratigraphy and geochronology of the terrestrial Eocene-Oligocene transition in North America. In: D.R. Prothero and W.A. Berggren (Editors), Eocene-Oligocene Climatic and Biotic Evolution. Princeton Univ. Press, Princeton, pp. 46-73.

Prothero, D.R., Denham, C.R. and Farmer, H.G., 1983. Magnetostratigraphy of the White River Group and its implications for Oligocene geochronology. Palaeogeogr. Palaeoclimatol. Palaeoecol., 42: 151-166.

Retallack, G.J., 1983. Late Eocene and Oligocene paleosols from Badlands National Park, South Dakota. Geol. Soc. Am. Spec. Pap., 193: 1-82.

Retallack, G.J., 1992. Paleosols and changes in climate and 
vegetation across the Eocene/Oligocene boundary. In: W.A. Berggren and D.R. Prothero (Editors), Eocene-Oligocene Climatic and Biotic Evolution. Princeton Univ. Press, Princeton, pp. 382-398.

Rozanski, K., Araguás-Araguás, L. and Gonfiantini, R., 1993. Isotopic patterns in modern global precipitation. In: P.K. Swart et al. (Editors), Climate Change in Continental Isotopic Records. Geophys. Monogr., 78: 1-36.

Sánchez Chillón, B., Alberdi, M., Bonadonna, F.P., Leone, G., Stenni, B. and Longinelli, A., 1994. Oxygen isotopic composition of fossil equid tooth and bone phosphate: An archive of difficult interpretation. Palaeogeogr. Palaeoclimatol. Palaeoecol., 107: 317-328.

Smuts, G.L., 1976. Reproduction in the zebra mare Equus burchelli antiquorum from the Kruger National Park. Koedoe, 19: 89-132.

Swisher III, C.C. and Prothero, D.R., 1990. Single crystal ${ }^{40} \mathrm{Ar} /{ }^{39} \mathrm{Ar}$ dating of the Eocene-Oligocene transition in North America. Science, 249: 760-762.
Van Valen, L., 1964. Age in two fossil horse populations. Acta Zool., 45: 93-106.

Wolfe, J.A., 1978. A paleobotanical interpretation of Tertiary climates in the Northern Hemisphere. Am. Sci., 66: 694-703.

Wolfe, J.A., 1992. Climatic, floristic, and vegetational changes near the Eocene/Oligocene boundary in North America. In: D.R. Prothero and W.A. Berggren (Editors), EoceneOligocene Climatic and Biotic Evolution. Princeton Univ. Press, Princeton, pp. 421-436.

Wolfe, J.A., 1993. A method of obtaining climatic parameters from leaf assemblages. U.S. Geol. Surv. Bull., 2040: 1-71.

Wolfe, J.A., 1994. Tertiary climatic changes at middle latitudes of western North America. Palaeogeogr. Palaeoclimatol Palaeoecol., 108: 195-205.

Zachos, J.C., Lohmann, K.C., Walker, J.C.G. and Wise, S.W., 1993. Abrupt climate change and transient climates during the Paleogene: a marine perspective. J. Geol., 101: 191-213. 